\title{
Non-destructive models to estimate leaf area on bell pepper crop
}

\author{
Modelos não-destrutivos para estimar a área foliar na cultura do pimentão
}

\author{
Richard Alberto Rodríguez Padrón ${ }^{\mathrm{I}}$ Sidinei José Lopes ${ }^{\mathrm{II}}$ Alexandre Swarowsky ${ }^{\mathrm{III}}$ \\ Roxanna Rosales Cerquera ${ }^{\text {IV }}$ Cicero Urbanetto Nogueira ${ }^{\text {IV }}$ Miguel Maffei $^{\mathrm{V}}$
}

\section{ABSTRACT}

The leaf area determination are extremely important in agronomic and physiological studies, as they provide valuable information in vegetable metabolism, methods used for this purpose should be accurate. This study aimed to develop polynomial models to estimate leaf area (LA). The methods used were leaf discs and Image $J^{\mathbb{B}}$ software, with measures of length $(L)$, width $(W)$, and relationship between length times width $(L W)$ in leaves of the bell pepper crop in two field trials with two hybrids: Arcade and Impacto, as well as, the correlation of values found when using the two methods. Through a random sampling, 560 leaves from each hybrid were selected, at different stages of crop growth. Regression analysis of $L A$ versus measures $L, W$ and $L W$ were performed by linear and quadratic models. The variable that best estimated LA was the relationship between $L W$ with linear model $\left(r^{2}=0.98\right)$. Measurements of length and width of leaves presented adjustment to quadratic model $r^{2}=0.93$ and $r^{2}=0.91$, respectively. The integrator model for all samples and both hybrids was: $L A=0.57 \times L W$. The destructive method of leaf discs showed high correlation $\left(r^{2}=0.99\right)$ with the non-destructive method of Image ${ }^{\mathbb{B}}$ software.

Key words: Capsicum annuum, ImageJ, leaf discs, individual leaf area, nondestructive methods.

RESUMO

A determinação da área foliar é importante, em estudos agronômicos e fisiológicos, para a obtenção de informações sobre o metabolismo vegetal e as técnicas utilizadas devem ser simples. $O$ objetivo deste estudo foi desenvolver modelos polinomiais para estimar a área foliar (AF). Foram utilizados os métodos de discos foliares e software ImageJ, com as medidas do comprimento (C) e da largura (L), e a relação entre o comprimento vezes a largura (CL) em folhas da cultura do pimentão, em dois ensaios com dois hibridos, Arcade e Impacto, e correlacionar os valores encontrados pelos dois métodos. Através de amostragem aleatória simples, foram selecionadas 560 folhas de cada híbrido, em diferentes estágios de crescimento da cultura. $A$ análise de regressão da área foliar versus as medidas de $C, L$ e $C L$ foi realizada por modelos lineares e quadráticos. A variável que melhor estimou a AF foi a relação entre o $C L$, pelo modelo linear com $r^{2}=0,98$. As medidas do comprimento e da largura das folhas apresentou ajustamento do modelo quadrática de $r^{2}=0,93$ e $r^{2}=0,91$, respectivamente. $O$ modelo integrador de todas as amostras, para ambos os hibridos, foi: $A F=0,57 \times C L$. $O$ método destrutivo por discos mostrou alta correlação $\left(r^{2}=0,99\right)$ com o método não destrutivo pelo ImageJ.

Palavras-chave: Capsicum annuum, ImageJ, discos foliares, área foliar individual, métodos não destrutivos.

\section{INTRODUCTION}

The determination of the leaf area is an important feature in physiological and agronomic studies, as it allows the estimation of the crop yield, among other characteristics. The plant leaf has a long petiole or an almost sessile foil, between lanceolate and ovate form, light green or dark and sometimes violet (NUEZ et al., 1996). Among other things, there is great diversity in the leaf, both in morphology as in the internal structure; these are responsible for

IPrograma de Pós-graduação em Engenharia Agrícola (PPGEA), Centro de Ciências Rurais (CCR), Universidade Federal de Santa Maria (UFSM), Av. Roraima, 1000, 97105-900, Santa Maria, RS, Brasil. E-mail: richardpadron@mail.ufsm.br. Corresponding author.

IIDepartamento de Fitotecnia, Centro de Ciências Rurais (CCR), Universidade Federal de Santa Maria (UFSM), Santa Maria, RS, Brasil.

IIICentro de Ciências Naturais e Tecnológicas, Engenharia Ambiental, Centro Universitário Franciscano (UNIFRA), Santa Maria, RS, Brasil.

${ }^{\mathrm{IV}}$ Colégio Politécnico da Universidade Federal de Santa Maria, Santa Maria, RS, Brasil.

${ }^{v}$ Engineering Department, University of The Andes (ULA), Venezuela. 
essentially functions as respiration, transpiration and photosynthesis (OLALLA et al., 2005). In addition, it is essential in the anabolic photosynthetic activities mediated by the chlorophyll pigments, which are very abundant in the leaves that play a role in the productivity, given its sensor role of incident solar radiation (HERBERT, 2004).

In this sense, the leaf is the main place where photosynthesis occurs. Therefore, the estimation of leaf area is necessary for the crop growth analysis. In the same way, with this process, plants are able to develop, through its ability to produce carbohydrates, not only by the surface but also by foliar efficiency. The basic data for individual plant growth analysis are weight of the whole plant or organs, as well as the leaf area, taken at regular intervals during the life cycle $\left(\mathrm{m}^{2}\right)$ or at the end of this (leaf area index). Also, the physiological processes that directly or indirectly affect the production capacity of the plants are estimated with growth rates, being the most significant, the development of the leaf area, and intensity of net assimilated and the development of the root system. Thus, the photosynthetic surface increases with the leaf area development and increase the dry mass accumulation. Therefore, this is a major factor for agronomic studies, such as the estimation of crop water needs, potential evapotranspiration, and water stress, among others.

Methods for measuring leaf area are mainly classified into two categories: destructive and non-destructive methods (MALAGI et al., 2010). The first have a high cost, requiring more intensive-labor, while the latter derives from more easily measurable parameters, low-cost and with high precision. GALINDO \& CLAVIJO (2007), they mentioned as well, that the latter presents a greater precision in the plant growth evaluation, as it facilitates its implementation in acicular or tubular leaves, in addition of performing the evaluation without destroying the plant leaves. This is a very consistent method compared to other indirect methods, taking into account that the estimation of leaf area from direct measurements have applicability even today, besides destructive methods usually required the collection of a large number of leaves, that in turn implies the use of expensive equipment and a longer dataset (ANTUNES et al., 2008).

Conversely other methods have been developed based on mathematical modeling of the relationship between the dimensions of the leave length, width and the relationship of the length by the width. These non-destructively methods are increasingly used, since they are an economical, quick, reliable way on the leaf area estimation (ZHANG \& PAN, 2011). The leaf area index is a dimensionless quantity, which presents the area of the sheet (top side only) per unit area of ground below it. It is expressed as leaf area per $\mathrm{m}^{2}$ of soil area and actively contributes to the transfer of surface heat and water evaporation (ALLEN et al., 2006). It is also an indicative parameter of plant growth. Among the various studies to estimate leaf area we can enumerate: Phaseolus vulgaris (MARTIN et al., 2013), Rosa hybrida (GAO et al., 2012), Solanum tuberosum (JADOSKI et al., 2012), Tropaeolum majus (LOPES et al., 2007), Castanea sativa (SERDAR \& DEMIRSOY, 2006), Prunus persica (DEMIRSOY et al., 2004) and particularly Capsicum annuum (BAKKER 1989; RAY \& SINGH 1989; KLÄRING et al., 1995; SWART et al., 2004; CARVALHO et al., 2011).

Therefore, the this study aimed to: (1) To develop models to estimate leaf area from two hybrid on bell pepper crop by using length, width and the relationship between length and width of leaves, when methods of leaf discs and Image $J^{\circledR}$ software are used; (2) To create polynomial models for each hybrid; (3) integrated model with two hybrid and; (4) to evaluate the correlation between methods used.

\section{MATERIALS AND METHODS}

This study was carried out between the months of October and March, during the years 2013-2014 and 2014-2015 at the experimental area of the Universidade Federal de Santa Maria, located at an altitude of 110 meters and geographically at coordinates $29^{\circ} 41^{\prime} 25^{\prime}$ 'S, 53 $3^{\circ} 48^{\prime} 42^{\prime \prime} \mathrm{W}$. The climate of the region, according to the Köppen classification is subtropical humid (Cfa). The soil is classified as typical dystrophic yellow loam soil (STRECK et al., 2008) and the description of physical and hydric-soil parameters of the experimental area described by PADRÓN et al. (2015). Weather data were collected and recorded from an automatic weather station located $1 \mathrm{~km}$ from the study area. The first field trial reached mean temperature of $24.78^{\circ} \mathrm{C}$, mean relative humidity of $72.96 \%$ and in the second trial the mean temperature was $24.0^{\circ} \mathrm{C}$ and mean relative humidity of $76.5 \%$.

Hybrids of bell pepper used was Arcade F1 (Topseed Premium) and Impacto (Seminis), and were transplanted on field 60 days after the emergency, with a separation between plants of $0.4 \mathrm{~m}$ and between rows of $1.0 \mathrm{~m}$ for the plants density was 2.5 plants $\mathrm{m}^{-2}$.

Drip systems were used, with tape of inserted drippers spaced at $0.2 \mathrm{~m}$ and flow of $0.8 \mathrm{~L} \mathrm{~h}^{-1}$, where drip tape was installed for each row of plants. Irrigation 
depth of $100 \%$ of ETc and daily watering frequency was applied. Crop reference evapotranspiration (ETo) was calculated based on the method of PenmanMonteith/FAO and crop evapotranspiration (ETc) with single crop coefficient for each phenological stage (ALLEN et al., 2006).

The experimental design was arranged in a randomized block with four replications. Assessments were carried out to intervals of 11 days, using simple random sampling, fifty leaves of different sizes per day were selected for the study, in the canopy, lower and middle part of the plant, for a total of 560 leaves per hybrid (total 1120 leaves), in different crop phenological stages: growth, development and production. Leaves were collected between 7 am and 8 am to maintain the turgor during the analysis.

Leaf area was determined by the methods of leaf discs and Image ${ }^{\circledR}$ software (Image Processing and Analysis in Java). In both methods the length (L, in $\mathrm{cm})$, width $(\mathrm{W}$, in $\mathrm{cm})$ and area $\left(\mathrm{A}\right.$, in $\left.\mathrm{cm}^{2}\right)$ of single leaves were determined. Measurements of total length from the base to apex of leaves and width of leaves in perpendicular of length, were made. Procedure, Image ${ }^{\circledR}$ software: in the laboratory, fresh leaves on a flat bed scanner on the same day of collection, were scanned. Also, contrast colors were applied to leaves become darker (black) for the analysis. Subsequently, leaf discs method: same group of leaves was used for measurements. To determine the length and width in leaves, a digital caliper was used. Also, three discs of known area of $0.28,0.79$ and $3.14 \mathrm{~cm}^{2}$ discs $^{-1}$ were used, to get better coverage of leaves area, to determine leaf area (LA) with the product of different discs obtained per leaves.

A regression analysis to determine the relationship between area, length and width was used. The length (L), width (W), product between length and width (LW) were considered to be the independent variables, and leaf area the dependent variable. Coefficient of determinations $\left(\mathrm{r}^{2}\right)$, mean square error (MSE), root mean square error (RMSE), error sum of squares (SSE) and prediction sum of squares (PRESS) were calculated. Linear $(y=a+b x)$ and quadratic $\left(\mathrm{y}=\mathrm{a}+\mathrm{bx}+\mathrm{cx}^{2}\right)$ models were developed. The final model was selected based on the combination of the highest $r^{2}$ to a level of significance of $5 \%$, the lowest MSE, the lowest RMSE, the lowest PRESS, and when the PRESS values are reasonably close to SSE. In addition, for two-dimensional models, involving LW and $\mathrm{L}^{2} \mathrm{~W}^{2}$, the variance inflation factor (VIF) and the tolerance value $(\mathrm{T})$ as stated by ROUPHAEL et al. (2010) and SOUZA et al. (2015) were used to test the collinearity. Models were generated individually for each hybrid (520 leaves per hybrid) and data from both hybrids were integrated to determine unique models with greater quantity of leaves (1120 leaves). Besides, the two methods were validated with the correlation of leaf area. The regression analysis were performed with the software SPSS $^{\circledR}$ version 20, and the graphics with the SigmaPlot ${ }^{\circledR}$ software of version 12.5.

\section{RESULTS AND DISCUSSION}

The averages, maximum, minimum and standard deviation for leaves area, length (L) and width, are shown in (Table 1). The area of leaves ranged from 2.5 to $53.4 \mathrm{~cm}^{2}$, the length from 2.06 to $12.8 \mathrm{~cm}$ and the width from 1.07 to $7.5 \mathrm{~cm}$. The smaller standard deviation was obtained in the measurements from Arcade. In the hybrid Arcade, leaf measurements were higher than hybrid Impacto. The leaf shape from the Impacto had narrow leaves (length=12.46; width=6.8); whereas, the Arcade had wider leaves (length=12.8; width=7.5). Relation between $\mathrm{L}$ and $\mathrm{W}$ of leaves represent linear regression lines for the different hybrid (Arcade $=0.64$ and Impacto=0.86). Degree of collinearity for twodimensional models was tested, where: VIF lie between 6.4-6.8 and $\mathrm{T}$ between $0.14-0.15$, indicating that $\mathrm{L}$ and $\mathrm{W}$ can be used without collinearity.

Parameters, mean square errors, root mean square error, predicted residual error sum of squares and coefficients of determination of models for each hybrid, are shown in (Table 2). The hybrid presenting better $\left(\mathrm{r}^{2}\right)$ was Impacto. Models were better adjusted to the

Table 1 - Average data comparison of length, width and area of leaves in two hybrid on bell pepper crop obtained by the methods of leaf discs and Image ${ }^{\circledR}$ software. Data derived from 1120 leaves.

\begin{tabular}{ccccccc}
\hline & & & & & & \\
& Area $\left(\mathrm{cm}^{2}\right)$ & Length $(\mathrm{cm})$ & Width $(\mathrm{cm})$ & Area $\left(\mathrm{cm}^{2}\right)$ & Length $(\mathrm{cm})$ \\
\hline Mean & 18.13 & 7.13 & 3.76 & 16.98 & 6.75 & Width $(\mathrm{cm})$ \\
$\mathrm{SD}^{\mathrm{t}}$ & 10.40 & 2.30 & 1.07 & 9.37 & 2.06 & 1.11 \\
$\mathrm{Max}^{\mathrm{z}}$ & 49.97 & 12.46 & 6.82 & 53.4 & 7.8 \\
$\mathrm{Min}^{\mathrm{k}}$ & 2.57 & 2.41 & 1.58 & 2.5 & 2.2 & 1.5 \\
\hline
\end{tabular}

${ }^{\mathrm{z}}$ Max: Maximum, ${ }^{\mathrm{k}} \mathrm{Min}$ : Minimum, ${ }^{\mathrm{t}} \mathrm{SD}$ : Standard deviation. 
quadratic model using L and W. SOUZA et al. (2015), reported that values of MSE, RMSE, and PRESS are also important to validate a model. According to SWART et al. (2004), models are improved when the quadratic terms were added. Also, BAKKER (1989) and SWART et al. (2004), indicated that the leaf area in Capsicum annuum, can be estimated only with the width of leaves. As well, KLÄRING et al. (1995), indicated that the leaf area of Capsicum might can be predicted based on a model with $\mathrm{L}^{2}$ only. Relationship between LW obtained the best coefficients of determination in both varieties $\left(r^{2}=0.99\right)$; however, this technique required more measurements, which would probably imply the use of higher working hours and a higher margin of error. Integrative regression models between hybrids for estimating the leaf area of single leaves on bell pepper crop, are shown in (Figure 1). Models are adjusted better to the equation of quadratic regression based on the length and width. Relationship between L and W obtained the best coefficients of determination in integrating both hybrids $\left(r^{2}=0.98\right)$ and the standard error of 1.28 . Models presented greater diversity but lower coefficient of determination. Also, the leaf area estimation was calculated with Equation 1 over the relationship between length and width. RAY \& SINGH (1989) commented about the above cases, they assumed that Y-intercept was equal to zero $(\mathrm{a}=0)$ and had little effect on the coefficients of determination $\left(\mathrm{r}^{2}\right)$. For simplicity, it would then be acceptable to use the ratio estimator $(\mathrm{LA}=\mathrm{a} \times \mathrm{LW})$, on the basis of the estimator LA. These constants (0.57-0.63) agree closely with those calculated for other crops.

Area $=0.57 \times \mathrm{LW}$
Correlations measured of leaf area determined between methods, are shown in (Figure 2). High correlations between calculated and measured leaf area were reported $\left(r^{2}=0.98\right)$ and the standard error of 1.59 when all the leaves are combined. Select models are reliable and can be useful for the estimation of LA with the relationship (W, L and LW) to be measured in situ, without destruction of the plant. SWART et al. (2004), estimated the leaf area with a nondestructive method in plants of different ages of Capsicum annuum. They described that with simple measures from the product of the length, the width and the relationship between the calculated and measured area was higher $\left(\mathrm{r}^{2}=0.996\right)$. Authors recommended that with only $25 \%$ of leaves in the total of the plant, it can be obtained an accurate total area.

The use of Image $J^{\circledR}$ software, presented a good result for determination of leaf area, either by scanned images or digital photography. MARTIN et al. (2013) mentioned that this method could be used in substitution of the integrated measure of leaf area (LI3100 LI-COR). In addition, TEWOLDE et al. (2005) added that AccuPAR can be used for estimation of leaf area, presenting some problems in the method validation. They presented some management considerations, for which minimizing errors associated with the estimates could carry out the measures. Analyzing one method against the another, due to management, when using an integrated measure of leaf area, the operator must be alert

Table 2 - models estimating the leaf area $\left(\mathrm{LA}, \mathrm{cm}^{2}\right)$ of single leaves in two hybrid on bell pepper crop with measures.from leaf length (L), width (W) and product of length times width (LW). Data derived from 560 leaves in each hybrid.

\begin{tabular}{|c|c|c|c|c|c|c|c|c|}
\hline \multirow{2}{*}{ Variable } & \multirow{2}{*}{ Model } & \multicolumn{3}{|c|}{--Parameters---------------- } & \multirow{2}{*}{ MSE } & \multirow{2}{*}{ RMSE } & \multirow{2}{*}{ PRESS } & \multirow{2}{*}{$r^{2}$} \\
\hline & & $a$ & $b$ & $c$ & & & & \\
\hline $\mathrm{L}$ & $\mathrm{LA}=\mathrm{a}+\mathrm{b}(\mathrm{L})$ & -12.75 & 4.3346 & & 2.9 & 1.7 & 1662.0 & 0.92 \\
\hline $\mathrm{L}$ & $\mathrm{LA}=\mathrm{a}+\mathrm{b}(\mathrm{L})+\mathrm{c}\left(\mathrm{L}^{2}\right)$ & 0.2665 & 0.5442 & 0.2591 & 2.45 & 1.57 & 1194.1 & 0.95 \\
\hline $\mathrm{W}$ & $\mathrm{LA}=\mathrm{a}+\mathrm{b}(\mathrm{W})$ & -17.236 & 9.4011 & & 2.66 & 1.63 & 1397.9 & 0.94 \\
\hline $\mathrm{W}$ & $\mathrm{LA}=\mathrm{a}+\mathrm{b}(\mathrm{W})+\mathrm{c}\left(\mathrm{W}^{2}\right)$ & -1.2905 & 0.4768 & 1.1529 & 2.16 & 1.47 & 945.9 & 0.96 \\
\hline $\mathrm{L} \times \mathrm{W}$ & $\mathrm{LA}=\mathrm{a}+\mathrm{b}(\mathrm{LW})$ & 0.0147 & 0.6233 & & 1.01 & 1.00 & 202.2 & 0.99 \\
\hline $\mathrm{L}$ & $\mathrm{LA}=\mathrm{a}+\mathrm{b}(\mathrm{L})$ & -11.929 & 4.2815 & & 3.21 & 1.79 & 4970.1 & 0.88 \\
\hline $\mathrm{L}$ & $\mathrm{LA}=\mathrm{a}+\mathrm{b}(\mathrm{L})+\mathrm{c}\left(\mathrm{L}^{2}\right)$ & 1.1816 & 0.9742 & 0.2326 & 2.99 & 1.73 & 4298.2 & 0.90 \\
\hline W & $\mathrm{LA}=\mathrm{a}+\mathrm{b}(\mathrm{W})$ & -12.917 & 7.7585 & & 3.69 & 1.92 & 6563.1 & 0.85 \\
\hline $\mathrm{W}$ & $\mathrm{LA}=\mathrm{a}+\mathrm{b}(\mathrm{W})+\mathrm{c}\left(\mathrm{W}^{2}\right)$ & -6.9983 & 4.6483 & 0.3773 & 3.75 & 1.94 & 6404.8 & 0.85 \\
\hline $\mathrm{L} \times \mathrm{W}$ & $\mathrm{LA}=\mathrm{a}+\mathrm{b}(\mathrm{LW})$ & 0.1903 & 0.603 & & 1.04 & 1.02 & 522.4 & 0.99 \\
\hline
\end{tabular}

MSE: Mean square errors, RMSE: root mean square error, PRESS: predicted residual error sum of squares, $\mathrm{r}^{2}$ : coefficients of determination. 


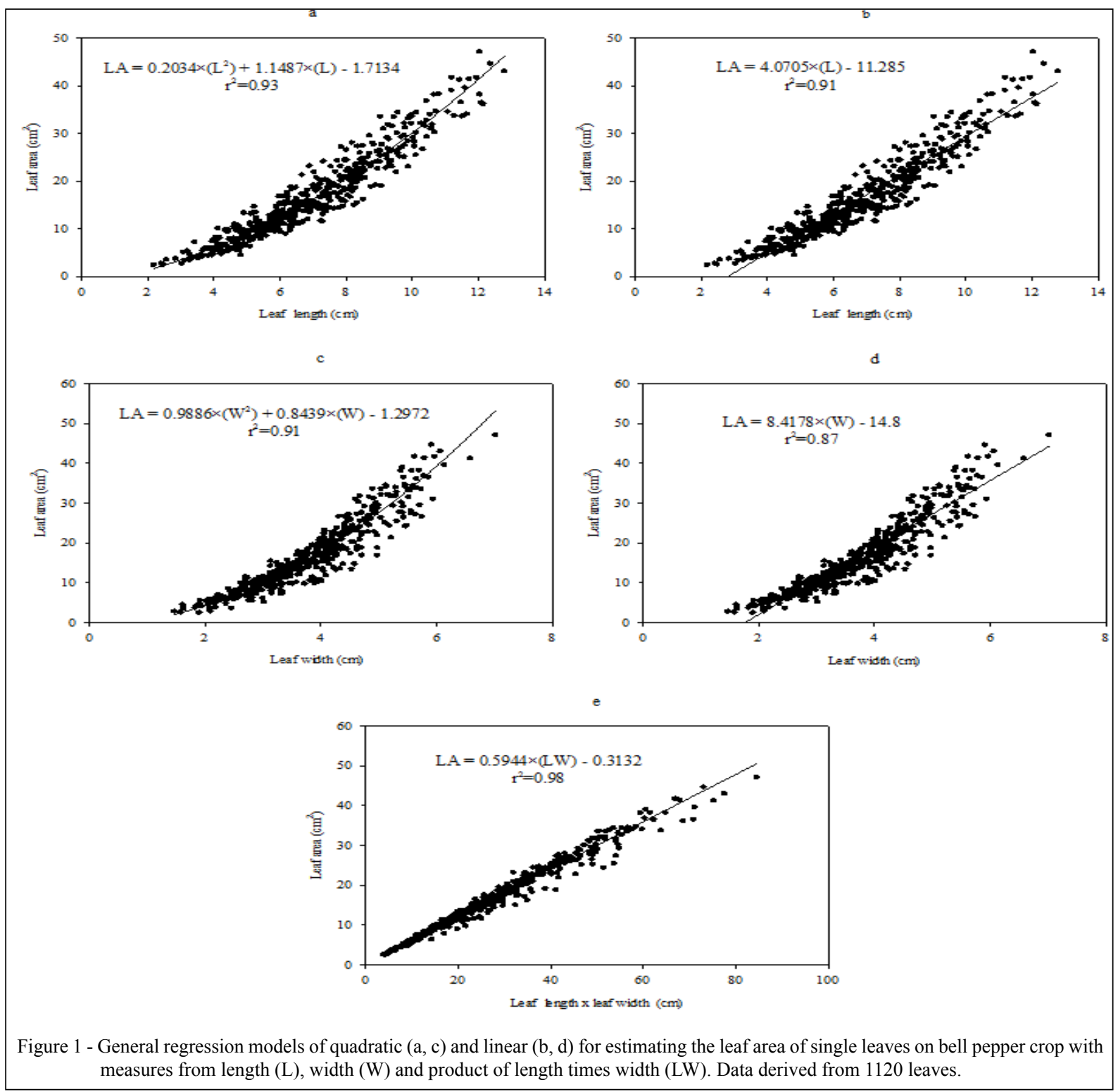

to some operation care, as for example, when passing the leaf by the computer, this should not be bent or superimposed, causing a non-estimation of the area. In the case of photography, the same could be repeated as many times as may be necessary, being error of this magnitude verified; however, the tilt of the picture could also cause changes in the measures, and the ideal is that the picture is done perpendicularly in relation to the leaves exposure.

For the estimation of the leaf area in large leaves, the models presented greater dispersion points in comparison with the medium and small leaves that the models are adjusted, significantly; in this case it is recommended the implementation of the product (LW) for its determination, as it is also mentioned by MARSHALL (1968). The ovalshaped leaves of bell pepper crop provided an excellent estimation with mathematical models such as those presented in this study. The non-destructive method as digital image used for estimating the leaf area, tend to be easy, fast, economical and non-destructive; in accordance with these characteristics it is possible to estimate leaf area with lower costs and accuracy. Consequently, the data presented in this paper showed an alternative to the estimation of leaf area.

\section{CONCLUSION}

The developed models by two-dimensions of relationship between length and width of leaves can estimate area leaf more accurately than those by single dimension as length or width. Using these models 


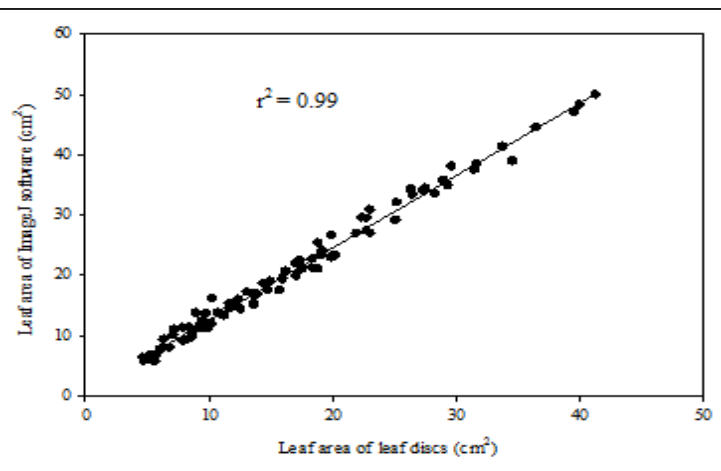

Figure 2 - Relationship between measured of leaf area determined from the methods of leaf discs and Image $J^{\circledR}$ software in bell pepper crop.

would enable researchers to make non-destructive measurements and repeated measurements on the same leaves. Methods used showed high correlation in estimation of leaf area. Models can accurately estimate the leaf area of single leaves without the use of any expensive instrument.

\section{ACKNOWLEDGEMENTS}

The authors thank the Colégio Politécnico da Universidade Federal de Santa Maria, the project of research number 036629 and Conselho Nacional de Desenvolvimento Científico e Tecnológico (CNPq)/process 469026/2014.

\section{REFERENCES}

ALLEN, R.G. et al. Crop evapotranspiration (guidelines for computing crop water requirements). Rome: FAO, 2006. p.298. (FAO. Irrigation and Drainage Paper N56).

ANTUNES, W.C. et al. Allometric models for non-destructive leaf área estimation in coffee (Coffea arabica and Coffea canephora). Annals of Applied Biology, v.153, p.33-40, 2008. Available from: $<$ http://dx.doi.org/10.1111/j.1744-7348.2008.00235.x>. Accessed: Jan. 20, 2015. doi:10.1111/j.1744-7348.2008.00235.x.

BAKKER, J.C. The effect of air humidity on growth and fruit production of sweet pepper (Capsicum annuum L.). Journal of Horticultural Science, v.64, p.41-46, 1989. Available from: $<$ http://dx.doi.org/10.1080/14620316.1989.11515925>. Accessed: Dez. 10, 2015. doi: 10.1080/14620316.1989.11515925.

CARVALHO, D.F. et al. Model adjustment for estimating bell pepper leaf area index and dry mass accumulation as a function of degree days. Semina: Ciências Agrárias, v.32, n.3, p.971982, 2011. Available from: <http://dx.doi.org/10.5433/16790359.2011v32n3p971>. Accessed: Dez. 15, 2015. doi: 10.5433/1679-0359.2011v32n3p971.

DEMIRSOY, $\mathrm{H}$. et al. Non-destructive leaf area estimation in peach. European Journal of Horticultural Science, v.69, n.4, p.144-146, 2004. Available from: <http://www.pubhort.org/ ejhs/2004/file_15102.pdf>. Accessed: 11 Nov. 2014.
GALINDO, J.R.; CLAVIJO, J. Allometric models for estimating the area of leaflets of pea (Pisum sativum L.). Revista Corpoica: Ciencia y Tecnologia Agropecuária, v.8, p.37-43, 2007. Available from: <http://www.redalyc.org/pdf/4499/449945022005.pdf>. Accessed: 11 Nov. 2014

GAO, M. et al. Estimation of leaf area for large scale phenotyping and modeling of rose genotypes. Scientia Horticulturae, v.138, p.227-234, 2012. Available from: <http://dx.doi.org/10.1016/j. scienta.2012.02.014>. Accessed: Ago. 03, 2015. doi: 10.1016/j. scienta.2012.02.014.

HERBERT, T.J. A simple model of canopy photosynthesis. Coral Gables: University of Miami. College of Arts and Sciences. Department of Biology, 2004. Available from: <http://www. bio.miami.edu/tom/courses/bil160/bil160goods/plantform/13b plantform.html>. Accessed: 14 Nov. 2014.

JADOSKI, S.O. et al. Method of determination of the leaf area of the potato cultivar Ágata from linear dimensions. Semina: Ciências Agrárias, v.33, Suppl.1,p.2545-2554,2012. Available from: $<$ http:// dx.doi.org/10.5433/1679-0359.2012v33Supl1p2545>. Accessed: Jan. 26, 2015. doi: 10.5433/1679-0359.2012v33Supl1p2545.

KLÄRING, H.P. et al. Growth of sweet pepper crop-measurements for modelling. International Symposium on Greenhouse Crop Models, v.417, p.107-112, 1995. Available from: <http://dx.doi. org/10.17660/ActaHortic.1996.417.12>. Accessed: Mai. 18, 2015. doi: 10.17660/ActaHortic.1996.417.12.

LOPES, S.J. et al. Leaf area and flower number of nasturtium in two plant densities. Horticultura Brasileira, v.25, n.2, p.159163, 2007. Available from: <http://dx.doi.org/10.1590/S010205362007000200006>. Accessed: Dez. 02, 2014. doi: 10.1590/ S0102-05362007000200006

MALAGI, G. et al. Non-destructive method for leaf area determination of grapevine 'brs-violeta' cultivar. Revista Brasileira de Fruticultura, v.32, n.4, p.1250-1254, 2010. Available from: $<\mathrm{http}$ ://dx.doi.org/10.1590/S0100-29452011005000005>. Accessed: Nov. 11, 2014. doi: 10.1590/S0100-29452011005000005.

MARSHALL, J.K. Methods for leaf area measurements of large and small samples. Photosynthetica, v.2, n.1, p.41-47, 1968.

MARTIN, T.N. et al. Using the ImageJ software to estimate leaf area in bean crop. Interciencia, v.38, n.12, p.843-848, 2013. Available from: <http://www.interciencia.org/v38 12/843.pdf $>$. Accessed: 10 Jan. 2015.

NUEZ, V.F. et al. El cultivo de pimientos, chiles y ajíes. Madrid: Mundi-Prensa, 1996. 607p.

OLALLA, M.F. et al. Agua y agronomía. Madrid: Mundi-Prensa, 2005. 606p.

PADRÓN, R.A.R. et al. Characterization physical-hydric of the yellow argisol soil for establishment of project and irrigation management. Acta Iguazu, v.4, n.1, p.36-47, 2015. Available from: <http://e-revista.unioeste. br/index.php/actaiguazu/article/view/12475>. Accessed: 21 Mar. 2015.

RAY, J.C.; SINGH, R.P. Leaf area estimation in Capsicum (Capsicum annuum L.). Scientia Horticulturae, v.39, n.3, p.181-188, 1989. Available from: <http://dx.doi.org/10.1016/0304-4238(89)90131-3>. Accessed: Nov. 29, 2014. doi: 10.1016/0304-4238(89)90131-3. 
ROUPHAEL, Y. et al. Modeling individual leaf area of rose (Rosa hybrida L.) based on leaf length and width measurement Photosynthetica, v.48, p.9-15, 2010. Available from: <http://dx.doi. org/10.1007\%2Fs11099-010-0003-x>. Accessed: Fev. 25, 2015. doi: 10.1007\%2Fs 11099-010-0003-X.

SERDAR, Ü.; DEMIRSOY, H. Non-destructive leaf area estimation in chestnut. Scientia Horticulturae, v.108, n.2, p.227-230, 2006. Available from: <http://dx.doi.org/10.1016/j.scienta.2006.01.025>. Accessed: Ago. 05, 2015. doi: 10.1016/j.scienta.2006.01.025.

SOUZA, M.C. et al. Non-destructive model to estimate the leaf area of multiple Vochysiaceae species. Brazilian Journal of Botany, v.38, n.4, p.903-9.09, 2015. Available from: <http:// dx.doi.org/10.1007/s40415-015-0176-4>. Accessed: Jun. 17, 2015. doi: $10.1007 / \mathrm{s} 40415-015-0176-4$.

STRECK, E.V. et al. Solos do Rio Grande do Sul. EMATER/RSASCAR, 2.ed. Porto Alegre (Brasil), 2008. 222p.
SWART, E.A.M. et al. Non-destructive estimation of leaf area for different plant ages and accessions of Capsicum annuum L. Journal of Horticultural Science and Biotechnology, v.79, n.5, p.764-770, 2004. Available from: <http://dx.doi.org/10.10 80/14620316.2004.11511840>. Accessed: Nov. 17, 2015. doi: 10.1080/14620316.2004.11511840.

TEWOLDE, H. et al. Estimating cotton leaf area index nondestructively with a light sensor. Agronomy Journal, v.97, n.4, p.1158-1163, 2005. Available from: <http://dx.doi.org/10.2134/ agronj2003.0112N>. Accessed: Ago. 18, 2014. doi: 10.2134/ agronj2003.0112N.

ZHANG, L.; PAN, L. Allometric models for leaf área estimation across different leaf-age groups of evergreen broadleaved trees in a subtropical forest. Photosynthetica, v.49, n.2, p.219-226, 2011. Available from: <http://dx.doi. org/10.1007/s11099-011-0027-x>. Accessed: Ago. 18, 2014. doi: 10.1007/s11099-011-0027-x. 